\title{
Absence of Hereditary p53 Mutations in 10 Familial Leukemia Pedigrees
}

\author{
Carolyn A. Felix, " Domenico D’Amico," Tetsuya Mitsudomi," Marion M. Nau, ${ }^{\ddagger}$ Frederick P. Li," Joseph F. Fraumeni, Jr.," \\ Diane E. Cole, ${ }^{\star}$ June McCalla, " Gregory H. Reaman,' Jacqueline Whang-Peng, ${ }^{\star \star}$ \\ Turid Knutsen,"* John D. Minna,"\# and David G. Poplack* \\ ${ }^{*}$ Pediatric, ${ }^{\ddagger}$ Navy Medical Oncology, "Epidemiology, and ${ }^{* *}$ Medicine Branches, National Cancer Institute, National Institutes of Health, \\ Bethesda, Maryland 20892; \$National Cancer Institute-Boston Field Station, Dana-Farber Cancer Institute, Boston, Massachusetts \\ 02115; 'Division of Hematology-Oncology, Children's National Medical Center, and Department of Pediatrics, The George Washington \\ University School of Medicine, Washington, District of Columbia 20010; and ${ }^{\ddagger}$ Simmons Cancer Research Center, \\ University of Texas Southwestern Medical Center, Dallas, Texas 75235
}

\begin{abstract}
Germline p53 mutations have been identified in the Li-Fraumeni syndrome but the role of such mutations in familial leukemia is not established. The p53 gene was examined by singlestrand conformation polymorphism analysis of exons 4-8 in 10 families with multiple members affected with leukemia. The diagnoses included acute and chronic leukemias and Hodgkin's disease. Identified in two families were p53 mutations that were nonhereditary. These included a 2-bp deletion in exon 6 found in the lymphoblast DNA of one child whose sibling, cousin, and several adult relatives had acute leukemia. The other nonhereditary p53 mutation was a transition at codon 248 (CGG to CAG, arginine to glutamine) found in the lymphoblasts of a patient with a preleukemic syndrome and acute lymphoblastic leukemia (ALL) whose brother is a long-term survivor of ALL. Thus, p53 mutations were found to occur in two families but both were nonhereditary. Moreover, in the remaining eight families no p53 mutation was identified in the regions of p53 where most mutations have been found in other cancers. Although p53 mutations sometimes may be present, they do not appear to be a primary event responsible for hereditary susceptibility to familial leukemia. This study suggests involvement of other genes or mechanisms. (J. Clin. Invest. 1992. 90:653-658.) Key words: acute lymphoblastic leukemia - germline mutation - somatic mutation • tumor suppressor gene
\end{abstract}

\section{Introduction}

Epidemiological studies have suggested that hematopoietic malignancies may cluster in families (1-4), but the molecular genetic basis for familial leukemia is not established. Recent studies have implicated involvement of the p53 gene in the Li-Fraumeni syndrome, another familial disorder of diverse primary cancers featuring bone and soft-tissue sarcomas, brain and breast cancer, adrenocortical carcinoma, and leukemia (5).

\footnotetext{
Address reprint requests to Dr. Felix, Division of Oncology, Department of Pediatrics, Room 9093, Children's Hospital of Philadelphia, 34th Street \& Civic Center Boulevard, Philadelphia, PA 19104.

Received for publication 12 March 1992 and in revised form 11 May 1992.
}

The Journal of Clinical Investigation, Inc.

Volume 90, August 1992, 653-658
The first evidence for possible involvement of $\mathrm{p} 53$ mutations in the pathogenesis of this syndrome was the observation of a similar spectrum of cancers in mice transgenic for a mutant p53 gene under its own promoter (6), and subsequent study soon demonstrated the presence of germline p53 mutations in Li-Fraumeni families $(7,8)$. A germline p53 mutation was observed in a Li-Fraumeni pedigree with one child affected with acute lymphoblastic leukemia (ALL) ${ }^{1}(9)$, and somatic p53 mutations have been identified in primary ALL, chronic lymphocytic leukemia (CLL) and chronic myelogenous leukemia (CML) and Burkitt lymphoma cells, as well as in several leukemia and lymphoma cell lines (9-12). It also may be noteworthy that the most common second malignant neoplasms in children with ALL are gliomas, which are the most common brain tumors observed in the Li-Fraumeni syndrome (13). However, in a family where three children had acute leukemia a p53 mutation present in lymphoblasts was nonhereditary (9). Although some p53 mutations are present in ALL cells at diagnosis, others have been identified in relapse specimens, and a role of mutant p53 in disease progression is also possible $(9,10)$. Alternatively, mutations at multiple tumor suppressor loci may be involved in some leukemias, as is the case for osteogenic sarcoma where both $\mathrm{Rb}$ and p53 are important and genetic susceptibility may be imparted by germline mutation in either (14-17). We thus undertook a study to determine whether mutations in the p53 gene are involved in the predisposition to familial leukemia.

\section{Methods}

Sample collection. A total of 10 leukemia-prone families were examined. Family histories were obtained by chart review or by interview, and materials were collected per protocol or as part of standard care. The diagnoses, individuals affected, individuals studied, ages, and times of sampling are as listed in Table I. Specimens analyzed included bone marrow (BM) or peripheral blood (PB) leukemic cells, BM or PB from affected individuals sampled during remission, cultured fibroblasts from affected individuals, and PB of unaffected relatives. The method for growth of fibroblasts in short-term culture has been de-

1. Abbreviations used in this paper: $\mathrm{ALL}$, acute lymphoblastic leukemia; BM, bone marrow; CLL, chronic lymphocytic leukemia; CML, chronic myelogenous leukemia; PB, peripheral blood; PCR, polymerase chain reaction; SSCP, single-strand conformation polymorphism. 
Table I. The p53 Gene in Familial Leukemia

\begin{tabular}{|c|c|c|c|c|c|c|c|c|c|c|}
\hline \multirow[b]{2}{*}{ Family } & \multirow[b]{2}{*}{ Member } & \multirow[b]{2}{*}{ Diagnosis } & \multirow{2}{*}{$\begin{array}{c}\text { Age at } \\
\text { diagnosis }\end{array}$} & \multirow[b]{2}{*}{ Sample } & \multirow{2}{*}{$\begin{array}{c}\text { Time of } \\
\text { sampling }\end{array}$} & \multicolumn{3}{|c|}{ SSCP (exon) } & \multirow[b]{2}{*}{ Codon } & \multirow[b]{2}{*}{ Mutation } \\
\hline & & & & & & 4 & $5-6$ & $7-8$ & & \\
\hline \multirow[t]{2}{*}{ I } & 1. Mother & ALL & 8 & PB & Remission & $\mathbf{N}$ & $\mathbf{N}$ & $\mathbf{N}$ & & \\
\hline & 2. Son & Pre-B ALL & 3 & BM & Diagnosis & $\mathbf{N}$ & $\mathbf{N}$ & $\mathbf{N}$ & & \\
\hline \multirow[t]{5}{*}{ II } & 1. Brother & ALL & 16 & NT & & & & & & \\
\hline & 2. Sister & Pre-B ALL & 28 & PB & Diagnosis & $\mathbf{N}$ & $\mathbf{N}$ & 7 & 248 & CGG to CAG \\
\hline & & & & $\mathbf{B M}$ & Relapse & $\mathbf{N}$ & $\mathbf{N}$ & $\mathbf{N}$ & & \\
\hline & 3. Father & Prostate cancer & 61 & PB & NA & $\mathbf{N}$ & $\mathbf{N}$ & $\mathbf{N}$ & & \\
\hline & 4. Mother & Unaffected & NA & PB & NA & $\mathbf{N}$ & $\mathbf{N}$ & $\mathbf{N}$ & & \\
\hline \multirow[t]{5}{*}{ III } & 1. Brother & AUL & 5 & NT & & & & & & \\
\hline & 2. Sister & Pre-B ALL & 5 & PB & Relapse & & 6 & & $214 / 215$ & $\operatorname{del} / \mathbf{f s}$ \\
\hline & 3. Father & Unaffected & NA & PB & NA & & $\mathbf{N}$ & & & \\
\hline & 4. Mother & Unaffected & NA & PB & NA & & $\mathbf{N}$ & & & \\
\hline & 5. Cousin & ALL & 2 & NT & & & & & & \\
\hline \multirow[t]{6}{*}{ IV } & 1. Cousin & ALL & 10 & NT & & & & & & \\
\hline & 2. Cousin & Pre-B ALL & 11 & CF & NA & $\mathbf{N}$ & $\mathbf{N}$ & $\mathbf{N}$ & & \\
\hline & 3. Cousin & Pre-B ALL & 4 & PB & Diagnosis & $\mathbf{N}$ & $\mathbf{N}$ & $\mathbf{N}$ & & \\
\hline & 4. Father of 3 & Unaffected & NA & PB & NA & $\mathbf{N}$ & $\mathbf{N}$ & $\mathbf{N}$ & & \\
\hline & 5. Mother of 3 & Unaffected & NA & PB & NA & $\mathbf{N}$ & $\mathbf{N}$ & $\mathbf{N}$ & & \\
\hline & 6. Half-sister of 1 & ALL & 5 & NT & & & & & & \\
\hline \multirow[t]{3}{*}{ V } & 1. Brother & AML & 14 & NT & & & & & & \\
\hline & 2. Sister & Pre-B ALL & 17 & PB & Diagnosis & $\mathbf{N}$ & $\mathbf{N}$ & $\mathbf{N}$ & & \\
\hline & & & & BM & Remission & $\mathbf{N}$ & $\mathbf{N}$ & $\mathbf{N}$ & & \\
\hline \multirow[t]{2}{*}{ VI } & 1. Brother & Pre-B ALL & 2 & NT & & & & & & \\
\hline & 2. Sister & Pre-B ALL & 7 & $\mathbf{B M}$ & Diagnosis & $\mathbf{N}$ & $\mathbf{N}$ & $\mathbf{N}$ & & \\
\hline \multirow[t]{2}{*}{ VII } & 1. Cousin & ALL & 2 & NT & & & & & & \\
\hline & 2. Cousin & Pre-B ALL & 5 & BM & Diagnosis & $\mathbf{N}$ & $\mathbf{N}$ & $\mathbf{N}$ & & \\
\hline \multirow[t]{5}{*}{ VIII } & 3272 & CLL & & $\mathrm{CF}$ & NA & $\mathbf{N}$ & $\mathbf{N}$ & $\mathbf{N}$ & & \\
\hline & Father & CLL & & NT & & & & & & \\
\hline & Brother & CLL & & NT & & & & & & \\
\hline & Brother & CLL & & NT & & & & & & \\
\hline & Sister & CLL & & NT & & & & & & \\
\hline \multirow[t]{3}{*}{ IX } & 2441 & Hodgkin's disease & & $\mathrm{CF}$ & NA & $\mathbf{N}$ & $\mathbf{N}$ & $\mathbf{N}$ & & \\
\hline & Brother & ALL & & NT & & & & & & \\
\hline & Brother & ALL & & NT & & & & & & \\
\hline \multirow[t]{8}{*}{$\mathrm{X}$} & 2642 & AML & & $\mathrm{CF}$ & NA & $\mathrm{N}$ & $\mathrm{N}$ & $\mathbf{N}$ & & \\
\hline & Brother & AML & & NT & & & & & & \\
\hline & Brother & AML & & NT & & & & & & \\
\hline & Cousin & MRE & & NT & & & & & & \\
\hline & Cousin & MRE & & NT & & & & & & \\
\hline & Cousin & AML & & NT & & & & & & \\
\hline & Great aunt & AML & & NT & & & & & & \\
\hline & Great uncle & AML & & NT & & & & & & \\
\hline
\end{tabular}

Family pedigrees III, VIII, and X have been reported in references 4, 9, and 3, respectively. Abbreviations used in this table are defined in footnote 1 plus the following: AUL, acute undifferentiated leukemia; CF, cultured fibroblasts; MRE, malignant reticuloendotheliosis; N, normal; NA, not applicable; NT, not tested.

scribed (7). The peripheral white blood cells of unaffected relatives were collected after an explanation of the studies to be performed. When performed, cytogenetic analysis was by standard methods (18).

Screening for mutations. High molecular weight DNA and total cellular RNA were isolated as described $(19,20)$. The polymerase chain reaction (PCR)/single-strand conformation polymorphism (SSCP) method as modified to screen for point mutations in the p53 gene in genomic DNA has been described (21).

Characterization of abnormalities suggested by screening. Mutations were confirmed by restriction enzyme digestion and/or direct sequencing of genomic DNA PCR products using described methodology (9). 


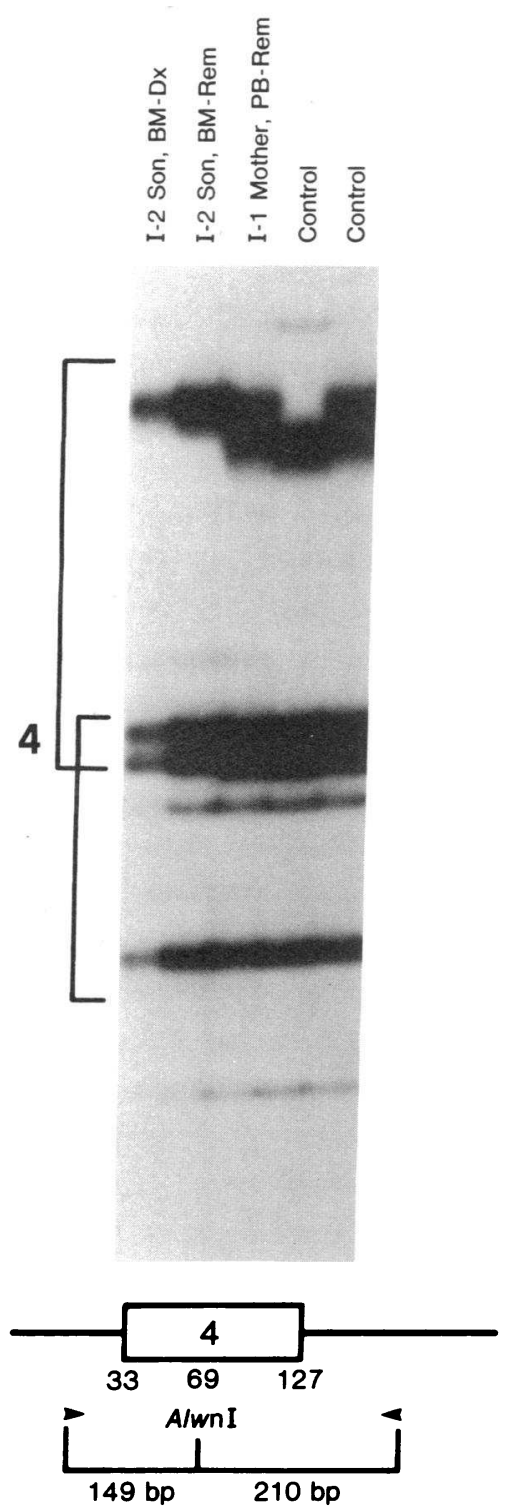

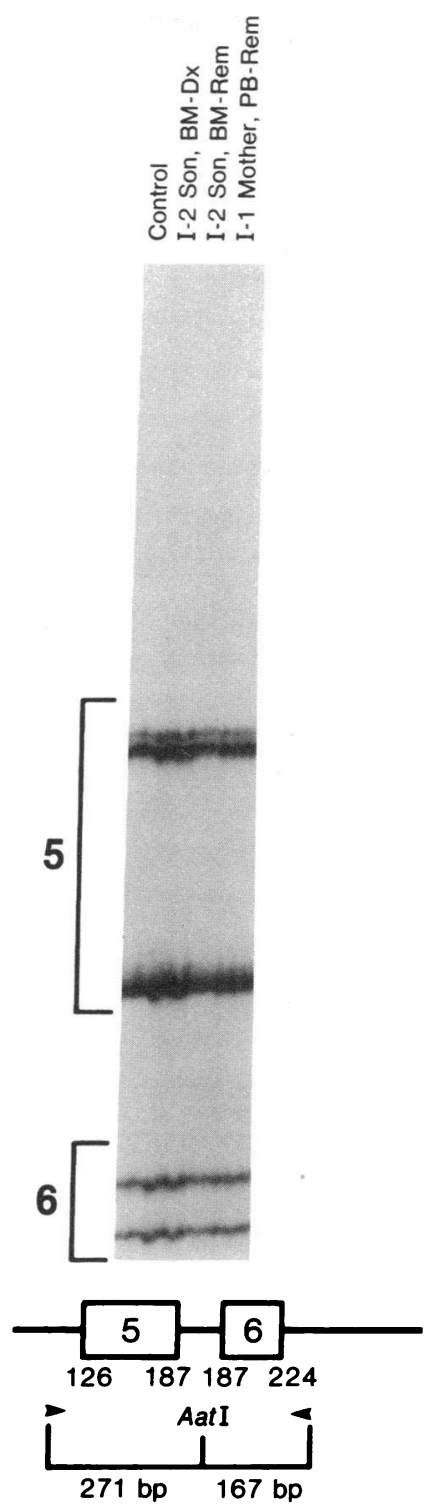

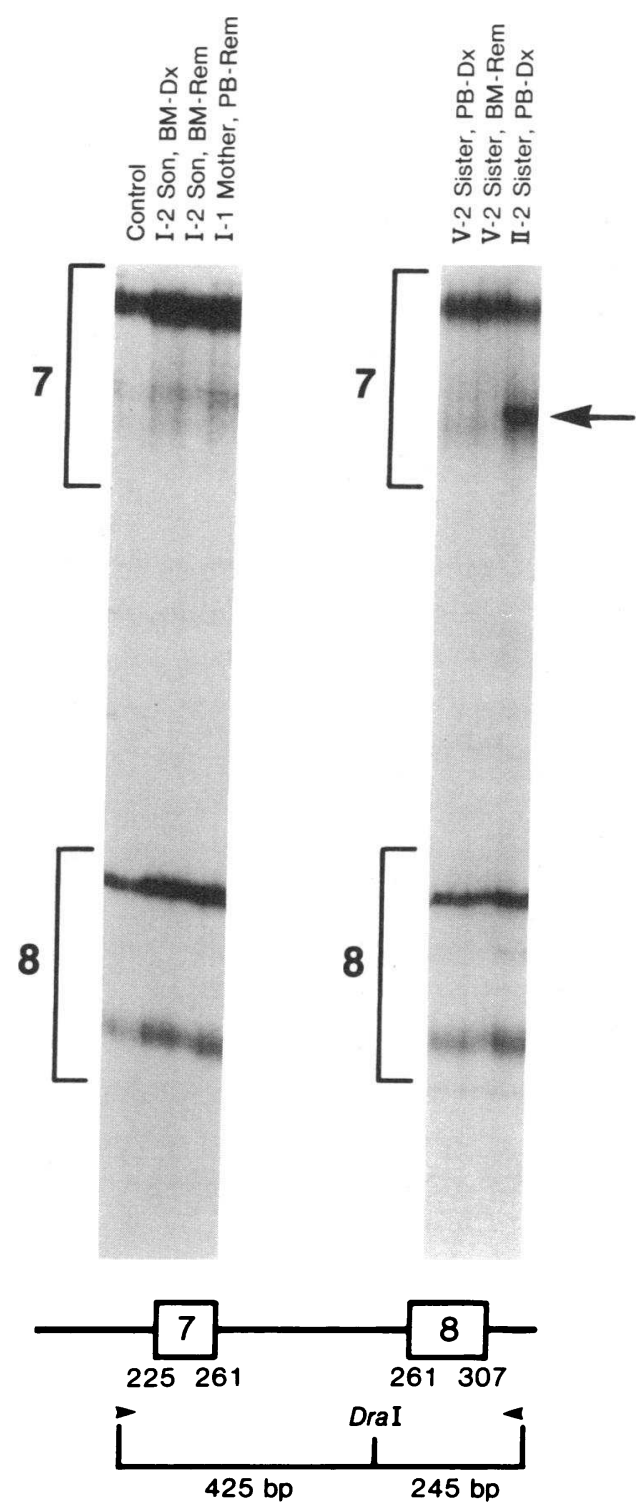

Figure 1. Examples of analysis of genomic DNAs of patients from three leukemia-prone families for the presence of p53 mutations by the PCR/SSCP method (21). Patients with leukemia were studied at diagnosis $(D x)$, relapse (not shown) or remission (Rem) as indicated. Samples shown were either BM or PB. BM or PB DNAs without p53 mutations which were derived from other previously studied patients (9) or from normal individuals served as controls. Pattern differences in the exon 4 panel are consistent with polymorphism at p53 codon 72 (21). Roman numerals indicate families. Sites of restriction enzyme cleavage in genomic DNA and resultant normal sizes of genomic DNA PCR fragments containing individual exons are shown by schematic (bottom). The arrow indicates mutation in II-2 which proved to be of somatic origin.

Family studies. For studies of unaffected family members SSCP analyses and restriction enzyme digestion or direct sequencing of genomic DNA PCR products were performed as appropriate to individual cases.

One leukemia-prone family listed in Table I was previously studied (family III) and the additional methods of analysis including the RNase protection assay and cDNA synthesis, cloning, and sequencing have been described (9).

\section{Results}

Absence of hereditary p53 mutations in familial $A L L$. Individuals including 13 patients and 5 unaffected relatives from 10 families were examined (Table I). SSCP analysis identified patterns suggestive of p53 mutations in the lymphoblast genomic DNA of two individuals. Although p53 mutations were con- firmed in the lymphoblasts of these two patients with ALL who were members of different leukemia-prone families (Table I, families II and III), both mutations were nonhereditary. Specimens from all of the other individuals studied had only normal patterns on SSCP analysis of exons 4-8 (see Fig. 1, families I and $\mathrm{V})$.

Characterization of p53 mutations in familial ALL. SSCP analysis of PB lymphoblast genomic DNA sampled at diagnosis from one of two siblings with ALL (family II) suggested both a normal p53 allele and an abnormal allele with a mutation in exon 7 (Fig. 1), which by direct sequencing was found to be a $G$ to A transition at codon 248 (CGG to CAG, arginine to glutamine). The mutation would obliterate the MspI restriction site normally present at codon 248 , and MspI digestion of a PCR amplified fragment of lymphoblast genomic DNA at diagnosis 


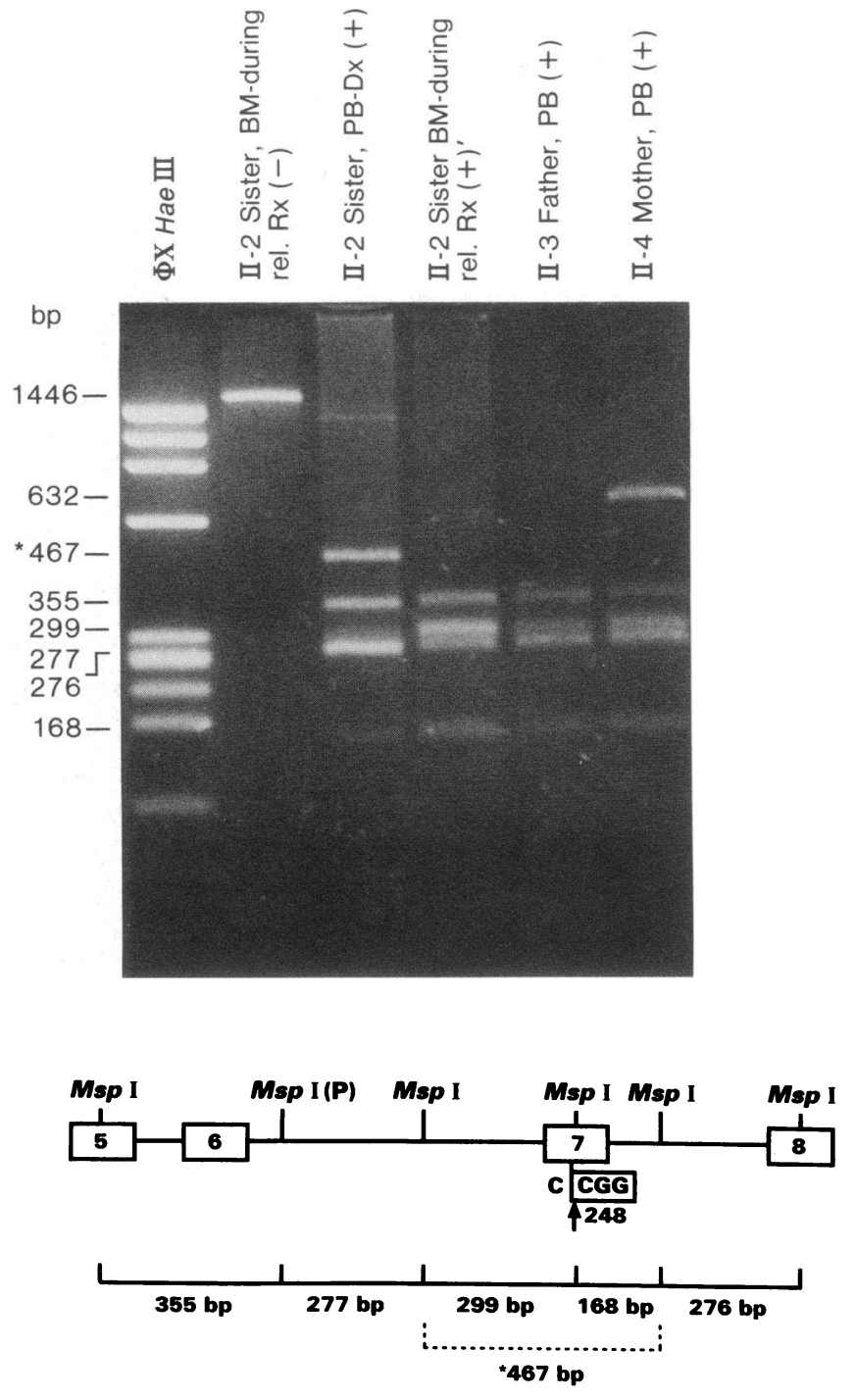

Figure 2. MspI digestion of genomic DNA PCR products for assessment of presence, zygosity, and heritability of p 53 codon 248 mutation in family II. A 1446 bp PCR fragment containing p53 exons 5-8 was amplified from genomic DNAs prepared from BM or PB mononuclear cells of the indicated family members. $(-)$, undigested; $(+)$, digested. The schematic at bottom shows sites of cleavage by MspI in normal genomic DNA with normal sizes of MspI restriction fragments indicated by solid brackets and the MspI site normally present at $\mathrm{p} 53$ codon 248 indicated by arrow. The presence of the same mutation found in PB of II-2 at diagnosis $(D x)$ would obliterate the MspI site at codon 248 and result in an abnormally sized MspI fragment of $467 \mathrm{bp}$ (dashed line bracket/*). Note patterns consistent with the presence of both mutant and wild-type alleles in PB of II-2 at Dx, wild-type pattern during therapy for relapse in a sample containing predominantly lymphoblasts ( $r e l R x$ ), and wild-type patterns in PB of both parents. The fragment of $632 \mathrm{bp}$ in PB of Mother (II-4) is consistent with the presence of an intron $6 \mathrm{MspI}$ polymorphism $(P)$ on one allele.

verified the presence of both mutant and wild type alleles (Fig. 2). In contrast, both SSCP analysis and MspI digestion of exon 7-containing genomic DNA PCR fragments from BM sampled during chemotherapy for relapse and from parental $P B$ revealed only normal patterns. These findings indicate that the p53 codon 248 mutation was not of germline origin, neither early somatic nor hereditary. In that the specimen sampled during relapse chemotherapy still contained predominantly lymphoblasts, these data also suggest that the original leukemic clone manifesting the $\mathrm{p} 53$ mutation at diagnosis had been obliterated (Fig. 2). The pedigree of this family (family II) with two siblings diagnosed with ALL at early ages is as shown in Fig. 3.

The detailed study of a child with relapsed B-cell precursor ALL in another leukemia-prone family (Pre-B ALL pt. 4, family III-2, Table I) has been described (9). Analyses of PB lymphoblast mRNA or genomic DNA by the RNase protection assay, SSCP analysis, sequencing of the p53 open reading frame, and direct genomic sequencing identified a homo- or hemizygous 2 bp deletion at p53 codons 214/215 which would cause a frame shift and create a premature TGA termination codon in exon 6. However, SSCP analysis and analysis of p53 sequence in parental genomic DNA indicated that this p53 mutation was likewise nonhereditary (Table I). Despite the acquired nature of this mutation, this patient had a brother and distant cousin with childhood acute leukemia plus a family history of leukemia, breast, gastrointestinal, and prostate cancers over four generations of adults (9).

\section{Discussion}

The impetus for this investigation of the p53 gene in familial leukemia was the demonstrated role of $\mathrm{p} 53$ mutations in hereditary susceptibility to other human cancers $(7,8)$, the reported finding of lymphoid tumors in mice transgenic for a mutant p53 gene (6), and the occurrence of somatic p53 mutations in some leukemias and lymphomas (9-12). In Li-Fraumeni families with breast cancers, sarcomas, and brain tumors, the presence of germline p53 mutations in a region containing codons $245,248,252$, and 258 suggested that mutant p53 was a cancer susceptibility gene $(7,8)$. A germline p53 mutation also was demonstrated in a Li-Fraumeni family where ALL was included among the spectrum of tumors (9). The spectra of tumors in Li-Fraumeni pedigrees, however, are distinct from those in families affected with leukemia but not other Li-Fraumeni syndrome-type cancers. The present study suggests that germline p53 mutations are not involved in familial aggregations of leukemia that do not have other components of the Li-Fraumeni syndrome.

In family II, despite the occurrence of childhood ALL in the sibling and prostate cancer in the father, a p53 mutation observed in the lymphoblasts of one young adult with B-cell precursor ALL was neither hereditary nor germline, and, moreover, it appeared to be obliterated by treatment. This codon 248 transition (CGG to CAG, arginine to glutamine) observed only at diagnosis would change an amino acid residue which falls in a highly conserved region of p53 involved in murine SV40 large T antigen binding $(22,23)$. p53 codon 248 is a GpC dinucleotide site and a "hotspot" for transitional mutations in other cancers, both sporadic and hereditary $(24,25)$. However, this mutation is distinct from the germline CGG to TGG transition (arginine to tryptophan) commonly found at codon 248 in Li-Fraumeni families $(7,8)$. It also differs from a codon 248 CGG to CCG transversion (arginine to proline) which was present in the lymphoblasts of an infant with ALL at relapse (9). The finding of retained heterozygosity in both cases of ALL suggests that mutations at p53 codon 248 may be involved in leukemic transformation by the postulated trans-dominant 


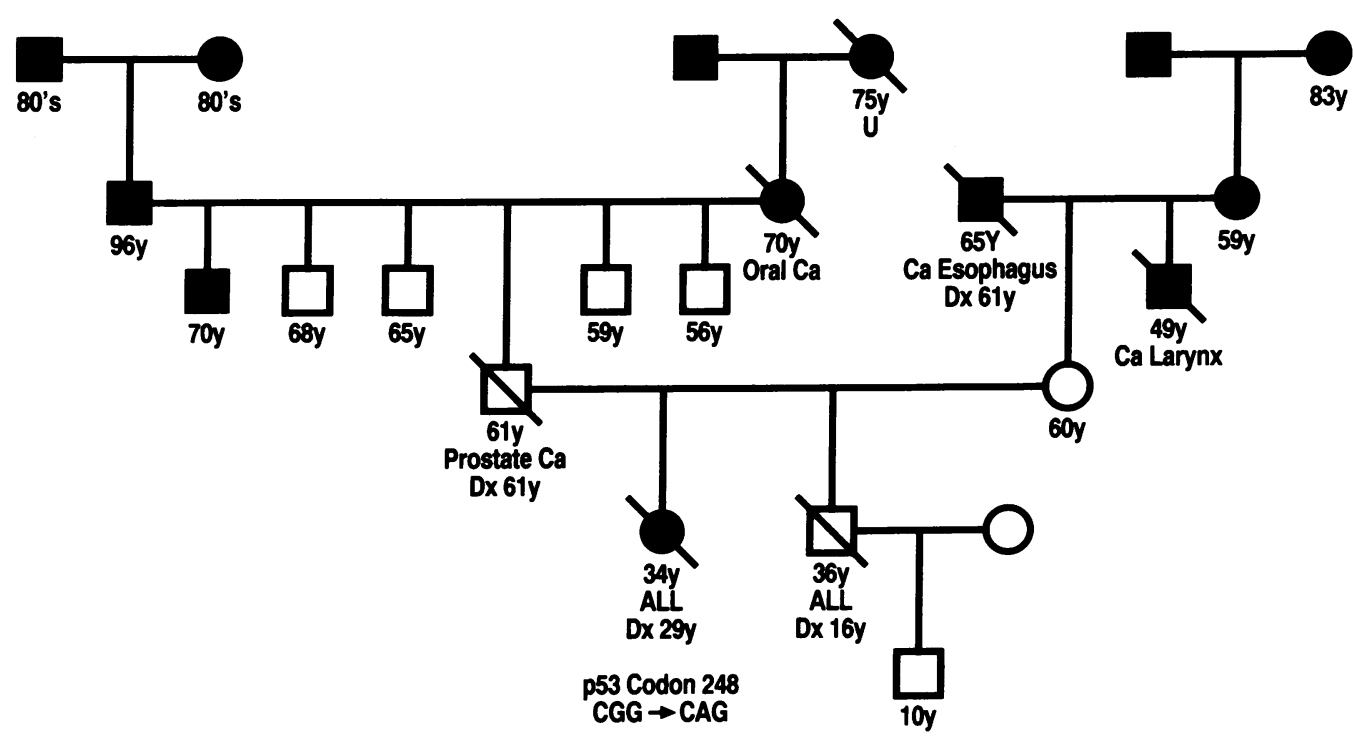

Figure 3. Pedigree of a leukemia-prone family (family II) with a somatic $\mathrm{p} 53$ mutation identified in II-2. Open box or circle indicates living male or female; solid box or circle, deceased; slash mark, affected with cancer; and $U$, cancer, type unknown.

negative mechanism $(9,26-28)$. These mutations at codon 248 may have a functional significance as each would replace a basic amino acid in the protein sequence with one that is nonbasic. The frequency at which this codon appears to be mutated in ALL cells, where p53 mutations are relatively uncommon, may prove to be disease-related.

The cluster of ALL in both siblings in family II in the absence of a germline p53 mutation suggests the involvement of another tumor suppressor gene, which in the heterozygous state is compatible with life, allows reproduction and may even provide a growth advantage. The brother has now survived his disease by 20 years and has fathered a son, whereas the sister had an indolent clinical course characterized by a preleukemic syndrome for 3 years before diagnosis. Likewise, although no p53 mutation was identified in family $I$, an affected mother survived to have an affected son. It is noteworthy that the leukemic cells of the son exhibited a hyperdiploid karyotype with several chromosomal gains including +3 in addition to the $\mathrm{t}(1 ; 3)(\mathrm{q} 34 ; \mathrm{p} 21)$. Chromosomal band $3 \mathrm{p} 21$ is commonly deleted in lung and renal cancers as well as in malignant lymphomas (29-31) and may be the site of another tumor suppressor gene.

The reported pedigree of another child with B-cell precursor ALL (Table 1, family III) also suggested hereditary susceptibility to cancer, including two other cases of childhood leukemia plus leukemia and other cancers over four generations of adults (9). However, the p53 codon 214/215 deletion was nonhereditary and differed in both location and type from the p53 mutations thus far reported in families affected with the $\mathrm{Li}$ Fraumeni syndrome $(7,8)$.

This study indicates that the frequency of $\mathrm{p} 53$ mutations in the regions of the gene most commonly mutated in other cancers is relatively low in familial leukemia ( 2 of 10$)$ and that when present such mutations are generally nonhereditary. The presence of nonhereditary p53 mutations in some cases may suggest involvement of mutations at multiple tumor suppressor loci in some leukemias, as is the case for osteogenic sarcoma where both $\mathrm{Rb}$ and p53 are important and genetic susceptibility may be imparted by germline mutation in either (14-17). Moreover, in contrast to Li-Fraumeni families, the majority of leukemia-prone families have no germline p53 mutation. Thus, although p53 mutations sometimes may contribute to the pathogenesis and/or progression of leukemias, they do not generally appear to be a primary event responsible for hereditary susceptibility. These results suggest that other genes or mechanisms may play a role in familial leukemia.

\section{Acknowledgments}

We thank P. Chumakov for providing the entire sequence of the human p53 gene and A. Meadows, B. Lange, C. Rubin, and C. Salem for helpful discussions.

\section{References}

1. Fraumeni, J. F., C. L. Vogel, and V. T. DeVita. 1969. Familial chronic lymphocytic leukemia. Ann. Intern. Med. 71:279-284.

2. Pendergrass, T. W., R. G. Stoller, D. L. Mann, R. H. Halterman, and J. F. Fraumeni. 1975. Acute myelocytic leukaemia and leukaemia-associated antigens in sisters. Lancet. 429-431.

3. Snyder, A. L., F. P. Li, E. S. Henderson, and G. J. Todaro. 1970. Possible inherited leukaemogenic factors in familial acute myelogenous leukemia. Lancet. 586-589.

4. Blattner, W., W. Strober, A. Muchmore, R. Blaese, and S. Broder. 1976. Familial chronic lymphocytic leukemia: immunologic and cellular characterization. Ann. Intern. Med. 84:554-557.

5. Li, F., and J. Fraumeni. 1969. Rhabdomyosarcoma in children. J. Natl. Cancer Inst. 43:1365-1373.

6. Lavigueur, A., V. Maltby, D. Mock, J. Rossant, T. Pawson, and A. Bernstein. 1989. High incidence of lung, bone, and lymphoid tumors in transgenic mice overexpressing mutant alleles of the p53 oncogene. Mol. Cell. Biol. 9:39823991.

7. Malkin, D., F. P. Li, L. C. Strong, J. J. Fraumeni, C. E. Nelson, D. H. Kim J. Kassel, M. A. Gryka, F. Z. Bischoff, M. A. Tainsky, et al. 1990. Germ line p53 mutations in a familial syndrome of breast cancer, sarcomas, and other neoplasms. Science (Wash. DC). 250:1233-1238.

8. Srivastava, S., A. Zou, K. Pirollo, S. Blattner, and E. Chang. 1990. Germline transmission of a mutated p53 gene in a cancer-prone family with Li-Fraumeni syndrome. Nature (Lond.). 348:747-749.

9. Felix, C. A., M. M. Nau, T. Takahashi, T. Mitsudomi, I. Chiba, D. G. Poplack, G. H. Reaman, D. E. Cole, J. J. Letterio, J. Whang-Peng, et al. 1992. Hereditary and acquired p 53 mutations in childhood acute lymphoblastic leukemia. J. Clin. Invest. 89:649-647.

10. Cheng, J., and M. Haas. 1990. Frequent mutations in the p53 tumor suppressor gene in human leukemia T-cell lines. Mol. Cell. Biol. 10:5502-5509.

11. Gaigano, G., P. Ballerini, J. Z. Gong, G. Inghirami, A. Neri, E. W. Newcomb, I. T. Magrath, D. M. Knowles, and R. Dalla-Favera. 1991. p53 mutations in human lymphoid malignancies: association with Burkitt lymphoma and chronic lymphocytic leukemia. Proc. Natl. Acad. Sci. USA. 88:5413-5417.

12. Sugimoto, K., H. Toyoshima, R. Sakai, K. Miyagawa, K. Hagiwara, H Hirai, K. Ishikawa, and F. Takaku. 1991. Mutations of the p53 gene in lymphoid leukemia. Blood. 77:1153-1156. 
13. Neglia, J., A. Meadows, L. Robison, T. Kim, W. Newton, F. Ruymann, H. Sather, and G. Hammond. 1991. Second neoplasms after acute lymphoblastic leukemia in children. $N$. Engl. J. Med. 325:1330-1336.

14. Friend, S., R. Bernards, S. Rogelj, R. Weinberg, J. Rapapport, D. Albert, and T. Dryja. 1986. A human DNA segment with properties of the gene that predisposes to retinoblastoma and osteosarcoma. Nature (Lond.). 323:643-650.

15. Mulligan, L., G. Matlashewski, H. Scrable, and W. Cavanee. 1990. Mechanisms of p53 loss in human sarcomas. Proc. Natl. Acad. Sci. USA. 87:5863-5867.

16. Masuda, H., C. Miller, H. Koeffler, H. Battifora, and M. Cline. 1987. Rearrangement of the p53 gene in human osteogenic sarcomas. Proc. Natl. Acad. Sci. USA. 84:7716-7719.

17. Iavarone, A., K. K. Matthay, T. M. Steinkirchner, and M. A. Israel. 1992. Germ-line and somatic p53 gene mutations in multifocal osteogenic sarcoma. Proc. Natl. Acad. Sci. USA. 89:4207-4209.

18. Tjio, J., and J. Whang. 1962. Chromosome preparations of bone marrow cells without prior in vitro culture or in vivo colchicine administration. Stain Technol. 37:17-20.

19. Felix, C. A., J. J. Wright, D. G. Poplack, G. H. Reaman, D. Cole, P. Goldman, and S. J. Korsmeyer. 1987. T cell receptor $\alpha$-, $\beta$-, and $\gamma$-genes in T cell and pre-B cell acute lymphoblastic leukemia. J. Clin. Invest. 80:545-556.

20. Felix, C. A., D. G. Poplack, G. H. Reaman, S. M. Steinberg, D. E. Cole, B. J. Taylor, C. G. Begley, and I. R. Kirsch. 1990. Characterization of immunoglobulin and T-cell receptor gene patterns in B-cell precursor acute lymphoblastic leukemia of childhood. J. Clin. Oncol. 8:431-442.

21. Mitsudomi, T., S. M. Steinberg, M. M. Nau, D. Carbone, D. D'Amico, S Bodner, H. K. Oie, I. Linnoila, J. S. Mulshine, J. D. Minna, et al. 1992. p53 gene mutations in non-small cell lung cancer cell lines and their correlation with the presence of ras mutations and clinical features. Oncogene. 7:171-180.
22. Soussi, T., C. Caron de Fromentel, and P. May. 1990. Structural aspects of the p53 protein in relation to gene evolution. Oncogene. 5:945-952.

23. Zakut-Houri, R., B. Bienz-Tadmaor, D. Givol, and M. Oren. 1985. Human p53 cellular tumor antigen: cDNA sequence and expression in COS cells. EMBO (Eur. Mol. Biol. Organ.) J. 4:1251-1255.

24. Levine, A. J., J. Momand, and C. A. Finlay. 1991. The p53 tumour suppressor gene. Nature (Lond.). 351:453-456.

25. Hollstein, M., D. Sidransky, B. Vogelstein, and C. C. Harris. 1991. p53 mutations in human cancers. Science (Wash. DC). 253:49-53.

26. Eliyahu, D., N. Goldfinger, O. Pinhasi-Kimhi, Y. Skurnik, N. Arai, V. Rotter, and M. Oren. 1988. Meth A fibrosarcoma cells express two transforming mutant p53 species. Oncogene. 3:313-321.

27. Hinds, P., C. Finlay, and A. Levine. 1989. Mutation is required to activate the p53 gene for cooperation with the ras oncogene and transformation. $J$. Virol. 63:739-746.

28. Milner, J., and E. A. Metcalf. 1991. Cotranslation of activated mutant p53 with wild type drives the wild-type p 53 protein into the mutant conformation. Cell. 65:765-774.

29. Whang-Peng, J., P. J. Bunn, C. Kao-Shan, E. Lee, D. Carney, J. Minna and A. Gazdar. 1982. A non-random chromosomal abnormality, del 3p(14-23) in human small cell lung cancer. Cancer Genet. Cytogenet. 6:119-134.

30. Whang-Peng J., T. Knutsen, A. Gazdar, S. Steinberg, H. Hoie, I. Linoila, J. Mulshine, M. Nau, and J. Minna. 1991. Non-random structural and numerical chromosomal changes in non-small cell lung cancer. Genes Chromosomes Cancer. 3:168-188.

31. Mitelman, F., Y. Kaneko, and J. Trent. 1990. Report of the Committee on Chromosome Changes in Neoplasia: proceedings of the Human Gene Mapping Meeting (10.5). Cytogenet. Cell. Genet. 55:358-386. 